\title{
Axotomy Results in Delayed Death and Apoptosis of Retinal Ganglion Cells in Adult Rats
}

\author{
M. Berkelaar, D. B. Clarke, Y.-C. Wang, G. M. Bray, and A. J. Aguayo \\ Centre for Research in Neuroscience, The Montreal General Hospital Research Institute and McGill University, Montréal, \\ Québec, Canada H3G 1 A4
}

\begin{abstract}
Using quantitative anatomical techniques, we show that after intraorbital optic nerve transection in adult rats, virtually all retinal ganglion cells (RGCs) survive for $5 \mathrm{~d}$ and then die abruptly in large numbers, reducing the RGC population to approximately $50 \%$ of normal by day 7 and to less than $10 \%$ on day 14. During this period of rapid cell loss, some RGCs show cytochemical alterations indicative of apoptosis ("programmed cell death"), a change not previously categorized after axotomy in adult mammals. With intracranial lesions 8$9 \mathrm{~mm}$ from the eye, the onset of cell death is delayed until day 8 and is greater with cut than crush.

The demonstration that axotomy results in apoptosis, the long interval between axonal injury and RGC death, and the different time of onset of the massive RGC loss with optic nerve lesions near or far from the eye suggest that axonal interruption triggers a cascade of molecular events whose outcome may be critically dependant on the availability of neuronal trophic support from endogenous or exogenous sources. The role of such molecules in RGC survival and the reversible nature of these injury-induced changes is underscored by the temporary rescue of most RGCs by a single intravitreal injection of brain-derived neurotrophic factor during the first $5 \mathrm{~d}$ after intraorbital optic nerve injury (MansourRobaey et al., 1994). The delayed pattern of RGC loss observed in the present experiments likely explains such a critical period for effective neurotrophin administration.
\end{abstract}

[Key words: neuron death, trophic factors, apoptosis, axotomy, retinal ganglion cells, programmed cell death]

Retinal ganglion cells, as well as other CNS neurons, may die as a result of axonal injury (Grafstein and Ingoglia, 1982; Allcutt et al., 1984; Misantone et al., 1984; Barron et al., 1986; VillegasPérez et al., 1993). In adult rats, for example, more than $90 \%$ of retinal ganglion cells (RGCs) die within 2 weeks of axotomy in the optic nerve (ON) near the eye (Villegas-Pérez et al., 1988). The mechanisms responsible for the loss of these and other axotomized CNS neurons are unclear but acute alterations in

\footnotetext{
Received July 26, 1993; revised Dec. 27, 1993; accepted Jan. 20, 1994.

The technical assistance of M. David, J. Laganière, J. Trecarten, and W. Wilcox is gratefully acknowledged. M. Berkelaar and D. Clarke were supported by Medical Research Council fellowships. The Medical Research Council of Canada and the Multiple Sclerosis Society of Canada provided financial support. The laboratory in which these studies were carried out is part of the Canadian Network for the Study of Neural Regeneration and Functional Recovery.

Correspondence should be addressed to Dr. Garth M. Bray, Centre for Research in Neuroscience, Montreal General Hospital, 1650 Cedar Avenue, Montréal, Québec, Canada H3G 1A4.
}

Copyright (C) 1994 Society for Neuroscience $0270-6474 / 94 / 144368-07 \$ 05.00 / 0$ cellular homeostasis, excitotoxicity, the local production of free radicals harmful to nerve cells, and a loss of trophic support from targets have all been implicated (for reviews, see Choi, 1992; Snider et al., 1993).

The importance of specific molecules for neuron survival is emphasized by the observation that certain growth factors can prevent the death of several classes of injured PNS and CNS neurons (e.g., Hendry and Campbell, 1976; Yip et al., 1984; Hefti, 1986; Williams et al., 1986; Sendtner et al., 1990; LaVail et al., 1992; Clatterbuck et al., 1993). In the rat retina, most axotomized RGCs are temporarily rescued when a single injection of brain-derived neurotrophic factor (BDNF) is administered into the vitreous chamber within the first $5 \mathrm{~d}$ after ON transection near the eye (Mansour-Robaey et al., 1994). Furthermore, during the first week after axotomy, the injured RGCs show little change in the expression of certain mRNAs and in the rates of slow axonal transport, but their values drop rapidly thereafter (McKerracher et al., 1990, 1993). The existence of an early period after axotomy when these CNS neurons appear capable of overcoming injury has lead us to investigate the characteristics of this axotomy-induced cell loss. For this purpose, we have defined further the patterns of early RGC loss after $\mathrm{ON}$ injury and examined the axotomized RGCs for cytologic evidence of apoptosis. This form of cell death can be due to the expression of genes involved in "programmed" cell death (Johnson and Deckwerth, 1993; Vaux, 1993), including that caused by the withdrawal of trophic support from neurons cultured in vitro (Martin et al., 1988; Batistatou and Greene, 1991).

\section{Materials and Methods}

Surgical procedures. In female Sprague-Dawley rats weighing 180-200 gm, RGCs were retrogradely labeled with Fluorogold (FG; $2 \%$ in $0.9 \%$ $\mathrm{NaCl}$ containing $10 \%$ dimethyl sulfoxide) applied to the surface of both superior colliculi (SC), as previously described for DiI (Vidal-Sanz et al., 1988). Seven days later, the left $\mathrm{ON}$ was interrupted intraorbitally or intracranially at distances of approximately $0.5 \mathrm{~mm}$ or $8-9 \mathrm{~mm}$ from the cyc. Two types of intracranial lesions were used: complete transection with scissors or crush for $20 \mathrm{sec}$ with jeweller's forceps; for the intraorbital lesions, the $\mathrm{ON}$ was cut with scissors.

For all procedures, the animals were anaesthetized with intraperitoneal $7 \%$ chloral hydrate $(0.42 \mathrm{mg} / \mathrm{gm}$ body weight), and treated according to The Guide to the Care and Use of Experimental Animals of the Canadian Council on Animal Care. Subcutaneous buprenorphine $(0.02 \mathrm{mg} / 250 \mathrm{gm}$ body weight $)$ was given as a postoperative analgesic.

Estimation of $R G C$ numbers. One to twenty-eight days after $\mathrm{ON}$ transection, the rats were deeply anesthetized and perfused with $4 \%$ paraformaldehyde. Both the left (lesioned $O N$ ) and right (uninjured control) retinas were dissected, fixed for an additional $30 \mathrm{~min}$, flatmounted on glass slides, and examined by fluorescence microscopy (excitation filter $355-425 \mathrm{~nm}$; barrier filter LP $460 \mathrm{~nm}$ ). RGC densities 

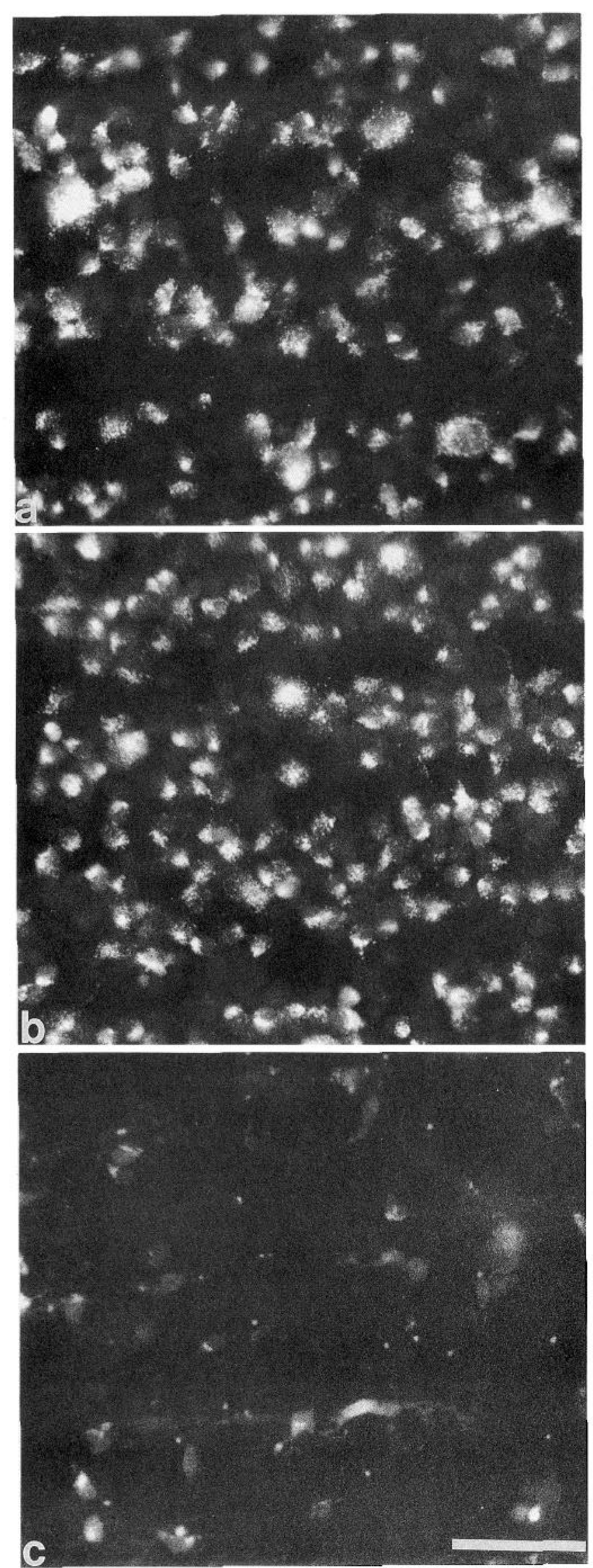

were calculated for experimental and control retinas by counting the number of FG-labeled neurons in three standard areas of each retinal quadrant (Villegas-Pérez et al., 1988). The data were analyzed by an analysis of variance and a post hoc Tukey protected $t$ test (GBSTAT, Dynamic Microsystems, Inc., Silver Spring, MD).

To validate the completeness of axonal interruption after $\mathrm{ON}$ crush, FG was applied to the SC of two animals immediately after ON crush and one animal after $\mathrm{ON}$ cut. The retinas from these animals, examined at 1 week (one crush, one cut) and 6 weeks (one crush), did not show FG labeling in the retina on the side of the ON lesion while the contralateral retina contained a normal population of FG-labeled cells.

Feulgen stain for DNA. Retinas from animals with one ON cut intraorbitally were fixed with $4 \%$ formaldehyde, frozen in liquid nitrogencooled isopentane, sectioned radially at $20 \mu \mathrm{m}$ thickness in a refrigerated microtome, and mounted on glass slides. To detect changes in the nuclei of axotomized RGCs, these retinal sections were processed with the Feulgen stain, which uses the Schiff reagent to demonstrate nuclear DNA (Clark, 1981).

In situ labeling of DNA fragmentation. Other retinas were processed for terminal deoxynucleotidyl transferase (TdT)-mediated deoxyuridine (dUPT)-biotin nick-end labeling (TUNEL) according to the method of Gavrieli et al. (1992) by incubating the frozen sections for $60 \mathrm{~min}$ at $30^{\circ} \mathrm{C}$ with TdT, biotinylated dUTP in TDT buffer $(30 \mathrm{~mm}$ Trizma base, pH 7.2, $140 \mathrm{~mm}$ sodium cacodylate, and $1 \mathrm{~mm}$ cobalt chloride). After rinses, the sections were processed for avidin-peroxidase activity. As positive controls, some sections were treated with DNase I $(1 \mu \mathrm{g} / \mathrm{ml}$; Sigma Chemical Co.) prior to the TUNEL reaction.

Light and electron microscopy of optic nerves. After fixation by perfusion with $4 \%$ formaldehyde in $0.1 \mathrm{~m}$ phosphate buffer, the optic nerves from the animals with intracranial lesions were dissected, postfixed in $2.5 \%$ glutaraldehyde $/ 0.5 \%$ formaldehyde and then osmium tetroxide, embedded in epoxy resin (Epon), and cut into $2 \mathrm{~mm}$ lengths prior to polymerization. Cross sections for light $(1 \mu \mathrm{m})$ and electron $(100 \mathrm{~nm})$ microscopy were stained with Malloy's azure II-methylene blue and lead citrate, respectively.

\section{Results}

FG-labeled RGCs were recognized by the fine, punctate fluorescence in the perinuclear cytoplasm and proximal dendrites (Fig. 1). In control retinas, the mean density of these labeled $\mathrm{RGCs}$ was $2144 \pm 176$ cells $/ \mathrm{mm}^{2}$ (mean $\left.\pm \mathrm{SD} ; n=8\right)$. These values, which correspond to the previously reported DiI-labeled RGC densities in control retinas of $2288 \pm 66$ cells $/ \mathrm{mm}^{2}$ (Villegas-Pérez et al., 1993), did not change during survival times of 1 week to 1 month.

Onset of RGC loss. After intraorbital ON transection close to the eye, the retinas' RGCs appeared normal (Fig. $1 a, b$ ) and the number of Fluorogold-labeled RGCs remained similar to those in the control retinas until day 5 (Fig. 2). Over the next $9 \mathrm{~d}$, however, most of these RGCs were lost so that the remaining population fell to $5 \%$ of control values by day 14 (Figs. $1 c, 2$ ).

With intracranial lesions, the pattern of RGC loss differed in two respects: the latency to the onset of RGC loss was longer and fewer RGCs were lost (Fig. 2). Seven days after intracranial cut of the ON, mean RGC densities $\left(2145 \pm 218\right.$ cells $\left./ \mathrm{mm}^{2}\right)$ were not significantly different $(p>0.05)$ from control values. On day 8 , however, RGC densities fell significantly $(p<0.01)$ to $66 \%$, with continued declines to $54 \%$ of controls by day 14 .

\footnotetext{
Figure 1. Retinal ganglion cells (RGCs) retrogradely labeled with Fluorogold: fluorescence photomicrographs of flat-mounted retinal segments approximately $1 \mathrm{~mm}$ from the optic disk. $a$, In a control retina, RGCs are labeled with punctate fluorescence. $b$, Three days after optic nerve transection close to the eye, the retina still appears normal. $c$, By $14 \mathrm{~d}$, the number of Fluorogold-labeled RGCs is markedly reduced. Some of the rounded, densely fluorescent cells are microglia, which phagocytose the Fluorogold from the disrupted neurons (Rinaman et al., 1991). Scale bar, $50 \mu \mathrm{m}$.
} 


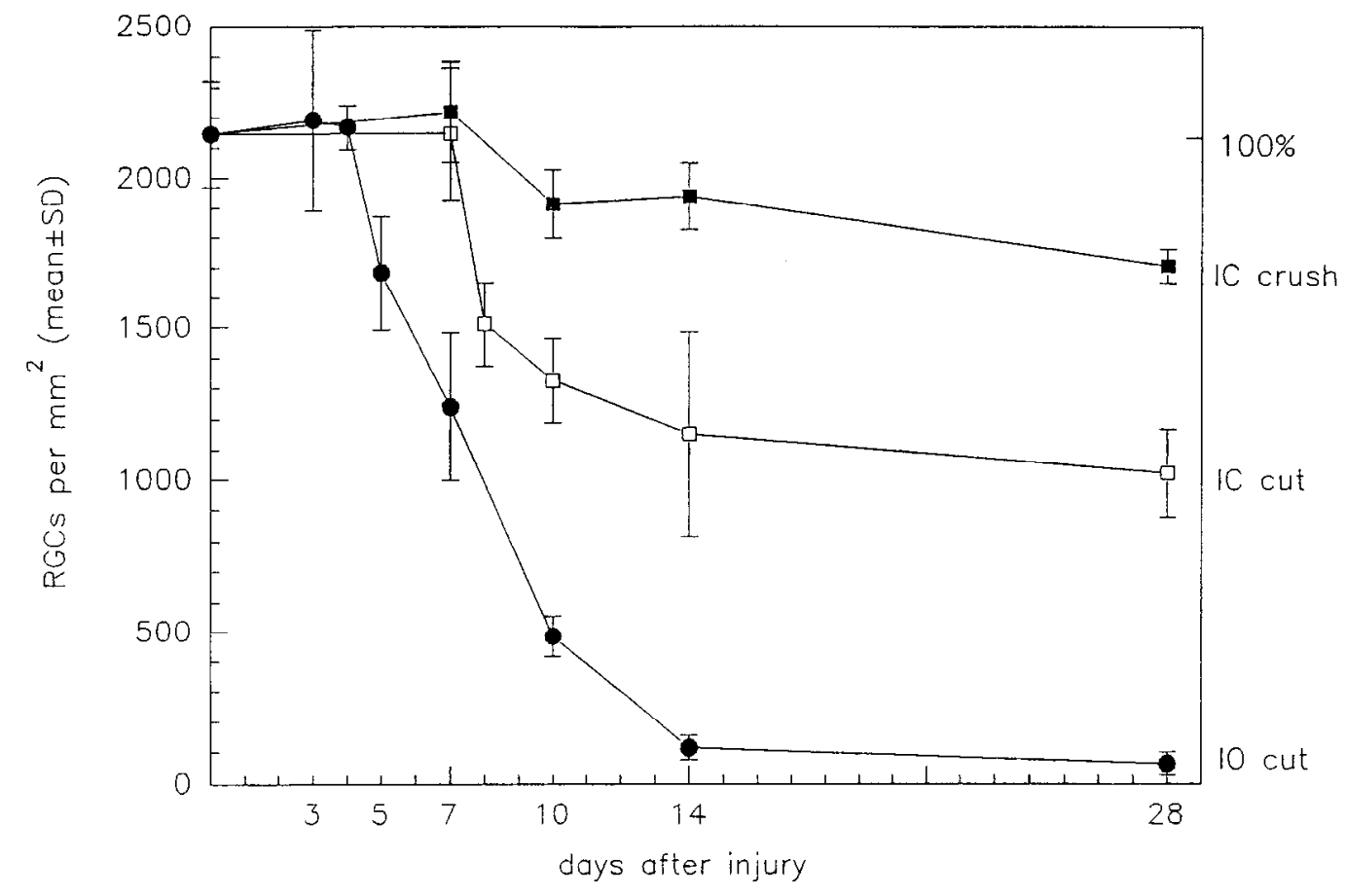

Figure 2. Densities (Fluorogold-labeled cells $/ \mathrm{mm}^{2}$ ) of RGCs in standard areas of flat-mounted retinas. Data points indicate mean \pm SD for groups of three to six experimental animals and eight control (day 0) animals. Solid squares, intracranial (IC) crush; open squares, intracranial cut; solid circles, intraorbital $(I O)$ cut. One-way ANOVA: $p<0.0 O 1$ for each of the three groups-IO cut, IC cut, and IC crush. Post hoc analysis within groups by the Tukey protected $t$ test: for IO cut on day 5 and later, and for IC cut on day 8 and later, the RGC densities were less than uninjured controls, $p<0.01$; for IC crush, RGC densities were significantly less than controls on day 10 and day $14(p<0.05)$, and on day $28(p<0.01)$.

Following intracranial ON crush, RGC loss was even less; RGC densities only decreased to $90 \%$ at 2 weeks and to $80 \%$ at 4 weeks (Fig. 2).

Cytologic changes in axotomized RGCs. Radial sections of control and axotomized retinas from rats with intraorbital ON transection were processed by the Feulgen reaction to identify changes in nuclear chromatin. On days 5 and 7, when RGC loss was intense (Fig. 2), one or two cells per section in the ganglion cell layer showed clumped and fragmented nuclei (Fig. 3). Nuclei showing such "apoptotic bodies" were not seen on days 1 or 3 after intraorbital axotomy or in the control retinas.

Five and six days after intraorbital ON cut, sections of retina, incubated with terminal deoxynucleotidyl transferase and biotinylated dUTP (Gavrieli et al., 1992), showed similar small numbers of nuclei in the ganglion cell layer that were peroxidase positive (Fig. 4). Such a finding indicated that these nuclei contained fragmented DNA, which is a hallmark of apoptosis (for reviews, see Bursch et al., 1990; Johnson and Deckwerth, 1993; Vaux, 1993). In control retinas, no nuclei in the ganglion cell layer showed this reaction.

The small number of nuclei showing apoptosis in these retinas is consistent with previous estimates that cells undergoing this type of death are eliminated in 3 hr or less (Bursch el al., 1990).

Histologic alterations in the injured optic nerves. The proximity of the intraorbital lesions to the eye precluded a detailed examination of surviving RGC axons in the short ON stump, in which the myelin rapidly degenerates and axonal sprouts develop during the first week after axotomy (Hall and Berry, 1989). After the intracranial lesions, however, it was possible to compare changes in the RGC axons in the ocular stump of the ON with the numbers of surviving RGCs. At 1 week, when
RGC counts were still normal, the ON segment $1-2 \mathrm{~mm}$ from the eye (Fig. $5 b$ ) resembled the control optic nerve (Fig. 5a). At 2 and 4 weeks after intracranial $c u t$, there were many disintegrating myelinated fibers (Fig. $5 d$ ) but even at 4 weeks, most fibers were intact after the intracranial crush (Fig. $5 c$ ).

\section{Discussion}

The results of these experiments show that virtually all RGCs survive axotomy for several days. Subsequently, and at predictable times that can be correlated with the site of the lesion in the ON, large numbers of RGCs are abruptly lost. The interval that separates the time of axotomy and the death of so many RGCs corresponds approximately to the period when most injured RGCs show little change in slow axonal transport (McKerracher et al., 1990), or in the expression of mRNAs for tubulin, neurofilament subunits, and glyceraldehyde-3-phosphate dehydrogenase (McKerracher et al., 1993). By the end of the first week after injury, however, there is a general fall in RGC expression of the mRNAs for these proteins to nearly onehalf of normal (McKerracher et al., 1990) and the rates of cytoskeletal transport along RGC axons in the ocular stump are decreased severalfold (McKerracher et al., 1990). In light of the present anatomical findings, these molecular changes in the overall population of RGCs may represent landmarks that separate an early stage, when most injured RGCs survive, from a subsequent period when many of these neurons become vulnerable to endogenous mechanisms capable of inducing cell death. The predictable timing of the axotomy induced changes in the RGCs should facilitate additional investigations of the molecular events involved in these phenomena and the implementation of measures to enhance neuronal survival. 
The existence of a window of opportunity for the early protection of these damaged neurons is further supported by the finding that the survival of many axotomized RGCs is enhanced by grafting a segment of peripheral nerve (PN) to the ocular stump of the ON at the time of transection (Villegas-Pérez et al., 1988). Such PN segments presumably act as an early source of critical molecules that influence neuronal survival (Heumann et al., 1987; Meyer et al., 1992). Furthermore, intravitreal injections of BDNF temporarily prevent the death of virtually all RGCs when administered during the first $5 \mathrm{~d}$ after axotomy (Mansour-Robaey et al., 1994). Recent studies of the effects of PN grafts and the administration of neurotrophins on RGC mRNAs for tubulin indicate that these experimental conditions result in enhanced tubulin gene expression (McKerracher et al., 1993). These overall findings further support the impression that some of the axotomy-induced changes in these CNS neurons are indeed reversible.

During the period of massive RGC loss after axotomy near the eye, some neurons in the ganglion cell layer exhibit nuclear fragmentation and histochemical staining indicative of DNA breakdown. These changes are considered to be morphologic correlates of apoptosis or "programmed cell death," a form of cell death that involves intrinsic cell mechanisms, including endonuclease activation and early DNA fragmentation (for reviews, see Bursch et al., 1990; Johnson and Deckwerth, 1993; Vaux, 1993). Apoptosis is usually associated with developmental or physiological forms of cell death but is also seen after axotomy in neonatal animals (Johnson and Deckwerth, 1993) or the withdrawal of trophic support of neural cells in vitro (Martin et al., 1988; Batistatou and Greene, 1991). In the retina, apoptotic death of RGCs has been observed during normal development (Harvey et al., 1990; Ilschner and Waring, 1992) but has not been identified after axotomy in adult animals. However, chromatin condensation, an ultrastructural change that is now recognized as a correlate of apoptosis, was previously described in RGC nuclei following ON injury (Barron et al., 1986). The rescuing effects of specific neurotrophins on injured RGCs (Clarke et al., 1993; Mansour-Robaey et al., 1994) and the present documentation of apoptosis in axotomized RGCs further suggest a role for trophic factor deprivation in the death of these CNS neurons.

The differences in the onset of RGC loss after ON injury near and far from the eye are puzzling. One possible explanation is that they reflect the time for retrograde transport of a signal from the end of the ON stump to the RGC nuclei. Singer et al. (1982) reported that a blockade of retrograde transport in motor nerves delayed axotomy-induced chromatolysis, suggesting that the induction of such changes depends on a transported signal. It is, however, difficult to conceive that such a putative message would take approximately $3 \mathrm{~d}$ to cover the $8-10 \mathrm{~mm}$ that separate the two sites of ON injury studied in our experiments if retrograde transport rates remain at $200 \mathrm{~mm} / \mathrm{d}$.

The loss of RGCs observed after sectioning the ON near the eye may also relate to the removal of the entire optic nerve as a source of trophic support for these neurons. While the in vivo dependency of nerve cells on growth factors arising from their glial environment in the CNS of adult mammals has not been proven, there is increasing evidence for the presence of growth factors and their receptors in glial cells of the PNS and CNS in general (Frisén et al., 1993; Korsching, 1993; Valenzuela et al., 1993) and in the rat optic nerve in particular (Jelsma et al., 1993a). The mRNAs for BDNF and NT-4, neurotrophins that

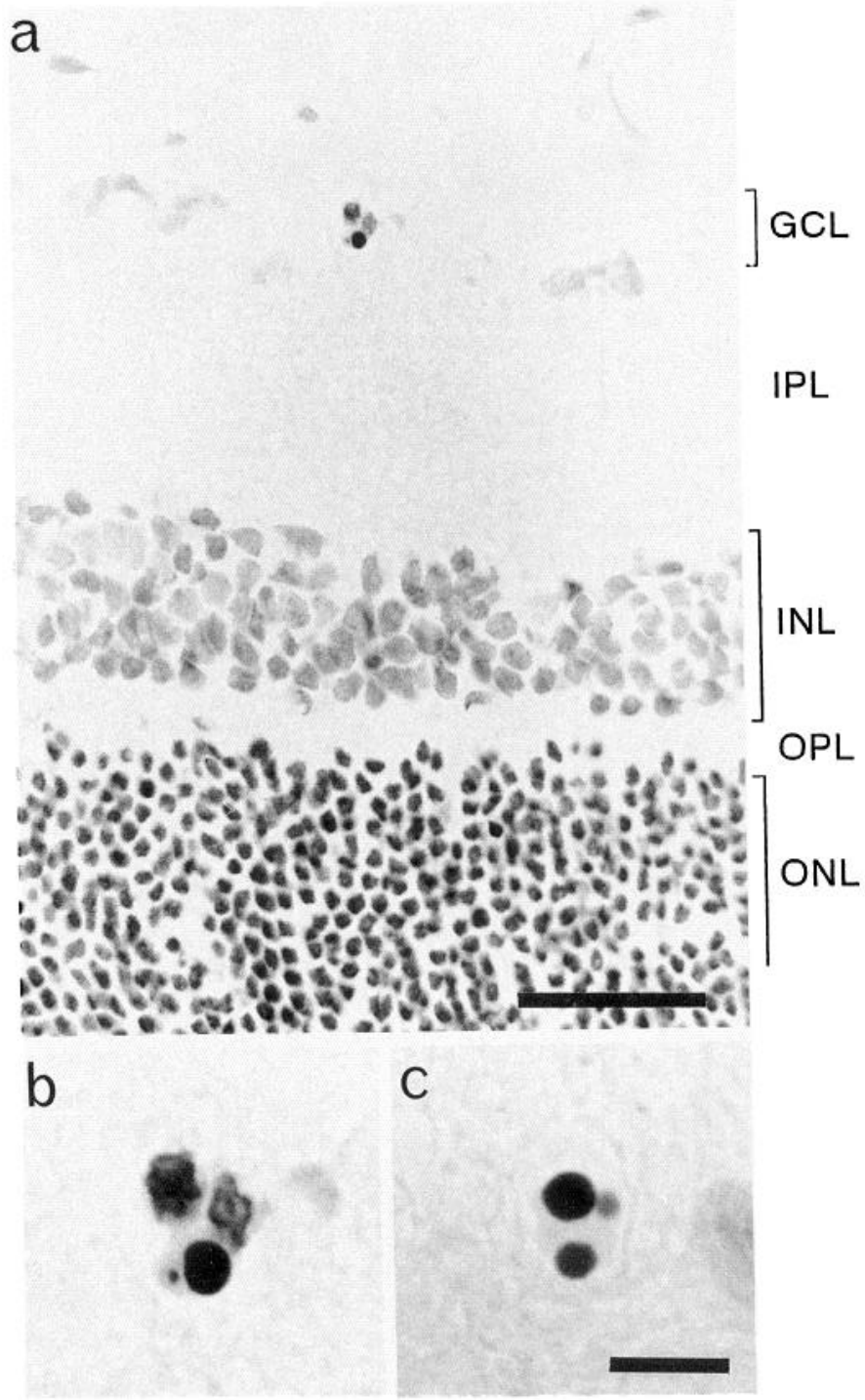

Figure 3. Fragmentation and shrinkage of nuclear chromatin ("apoptotic bodies") in retinal cells $5 \mathrm{~d}$ after optic nerve cut close to the eye. Radial sections of retina were processed by the Feulgen method to visualize nuclear DNA. $a$, Low-power micrograph showing the shrunken nucleus of a cell in the retinal ganglion cell layer. $G C L$, ganglion cell layer; $I P L$, inner plexiform layer; $I N L$, inner nuclear layer; $O P L$, outer plexiform layer; $O N L$, outer nuclear layer. $b$, In this enlargement of the cell shown in $a$, two other cells, possibly microglia, are adjacent to the apoptotic dying cell. $c$, Another example of nuclear shrinkage and fragmentation in a presumed retinal ganglion cell. Scale bars: $a, 35 \mu \mathrm{m} ; b$ and $c, 7 \mu \mathrm{m}$.

promote the survival of RGCs in vitro (Johnson et al., 1986; Thanos et al., 1989; Cohen et al., 1993) and in vivo (Clarke et al., 1993; Mansour-Robaey et al., 1994), have been identified in the intact ON and eye (Jelsma, 1993a; T. N. Jelsma, D. B. Clarke, A. J. Aguayo, and G. M. Bray, unpublished observations), and BDNF is transported retrogradely along rat RGC axons (Beer et al., 1993). If the expression of these molecules were maintained (Jelsma et al., 1993b) or transiently upregulated in the injured $\mathrm{ON}$, as has been described for NGF mRNA in ON stump (Lu et al., 1991), it might temporarily sustain axotomized RGCs disconnected from their targets. Thus, the survival of a greater number of RGCs when a longer ON stump 
DNAase control

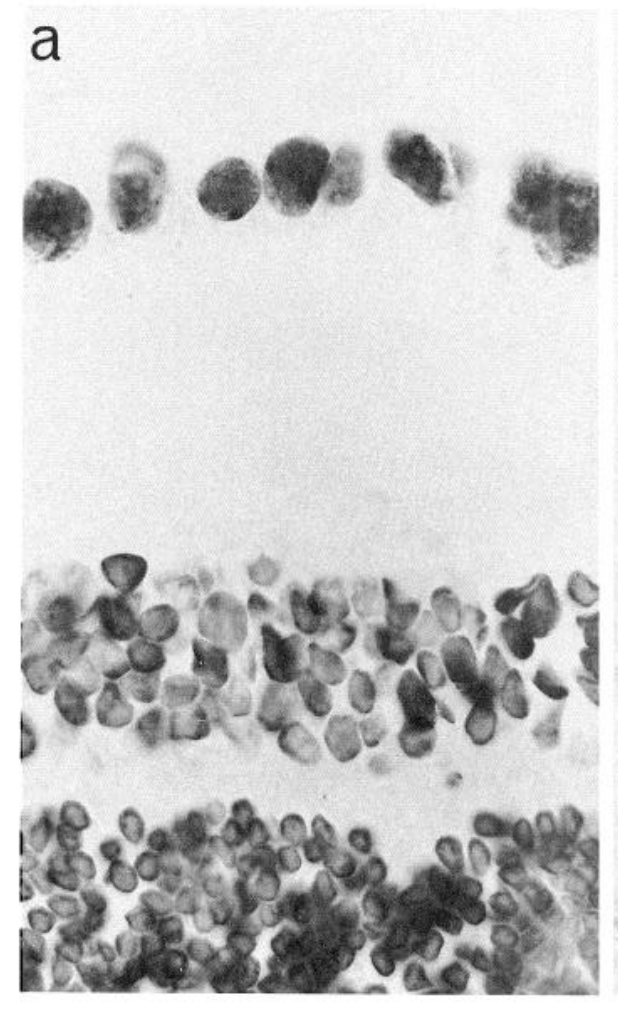

10 cut 5 days
Figure 4. In situ labeling of fragmented DNA. Radial sections of retina were processed for terminal deoxynucleotidyl transferase (TdT)-mediated dUPT-biotin nick-end labeling (TUNEL), and then incubated for peroxidase activity (Gavrieli et al., 1992). $a$, In a section of retina incubated with DNase prior to the TUNEL reaction, nuclei in all retinal layers are peroxidase positive. $b$, In a retina $5 \mathrm{~d}$ after optic nerve section close to the eye, there is a shrunken, peroxidase-positive cell nucleus in the ganglion cell layer $(G C L)$. Such staining indicates the presence of fragmented DNA, an early manifestation of apoptosis. In retinas with intact optic nerves, no nuclei in the ganglion cell layer showed this reaction, although some peroxidase reaction product was often present in the outer nuclear layer $(O N L) . I P L$, inner plexiform layer; $I N L$, inner nuclear layer; $O P L$, outer plexiform layer. Scale bar, $35 \mu \mathrm{m}$.

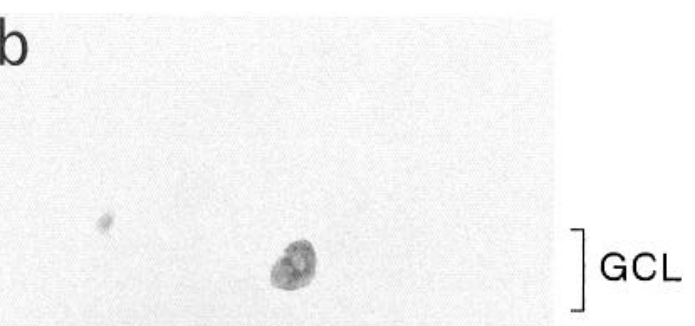

IPL

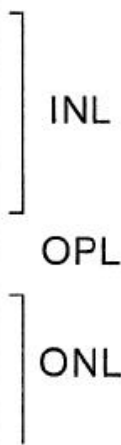

remains attached to the eye may reflect a larger source of these molecules from ON glial cells.

While the onset of RGC loss became apparent at similar times after both intracranial cut and crush, there were differences in the number of RGCs that survived after these intracranial lesions: $90 \%$ for crush and approximately 50\% for cut after 2 weeks. Changes in the ON stump might also explain the relationship between the extent of RGC loss and the type of intracranial ON lesion. After intracranial ON cut, a core of myelinated fiber loss and macrophage infiltration extends from the injury site to within 3-4 mm of the eye (Grafstein and Ingoglia, 1982; Richardson et al., 1982; Berkelaar, 1992). In contrast, the zone of severe injury only extended 1-2 mm toward the eye after intracranial crush and many axons were still intact at 1 month (Berkelaar, 1992). The greater numbers of glial cells that survive in the proximal ON stump after crush injury may be a source of trophic molecules that contribute to the increased survival of the RGCs after this type of injury. In addition, changes within the cut $\mathrm{ON}$, including the presence of large numbers of macrophages (Berkelaar, 1992), may generate noxious molecules that further threaten the survival of RGCs under precarious trophic support (Thanos et al., 1993).

In summary, the overall hypothesis proposed from these ex- periments is that the severing of the RGC axons triggers a cascade of molecular events that result in the apoptotic death of many of the injured neurons several days after axotomy. These neurons may die when changes in gene expression signaled by intrinsic and extrinsic perturbations at the site of injury in the $\mathrm{ON}$ are accompanied by a deficit in trophic support from their targets and their non-neuronal environments. Most of the neurons that die seem to do so suddenly and only the evanescent cytologic features of apoptosis anticipate their rapid disappearance from the retina. The onset of RGC loss appears to coincide with a general shift in gene expression and a slowdown in the transport rates of cytoskeletal proteins (McKerracher et al., 1990, 1993). Because this shift appears to involve all axotomized neurons in the retina, it may indicate the time when changes in gene expression induced by injury render the RGC particularly vulnerable to apoptotic death. While the loss of the cells whose trophic support is withdrawn in vitro is only delayed by a few hours (Martin et al., 1988; Batistatou and Greene, 1991), RGC survival in vivo may be initially extended by a limited provision of critical molecules from ON stores (Jelsma et al., 1993b). Because other experiments indicate that the intravitreal injection of certain neurotrophins can further lengthen RGC survival (Mansour-Robaey et al., 1994; Clarke et al., 1993), it seems

Figure 5. Electron micrographs of optic nerve $(\mathrm{ON})$ cross-sections 1-2 $\mathrm{mm}$ from the eye. $a$, Control ON. Myelinated axons of various size are grouped in bundles separated by astrocyte processes. $b$. Intracranial cut, 1 week. Most myelinated fibers still appear normal. $c$, Intracranial cut, 1 month. There is extensive degeneration of many myelinated fibers. $d$, Intracranial crush, 1 month. Most myelinated fibers remain intact near the eye. The ON stump had a similar appearance to within $1.5 \mathrm{~mm}$ of the crush site (not illustrated). Scale bar, $11 \mu \mathrm{m}$. 


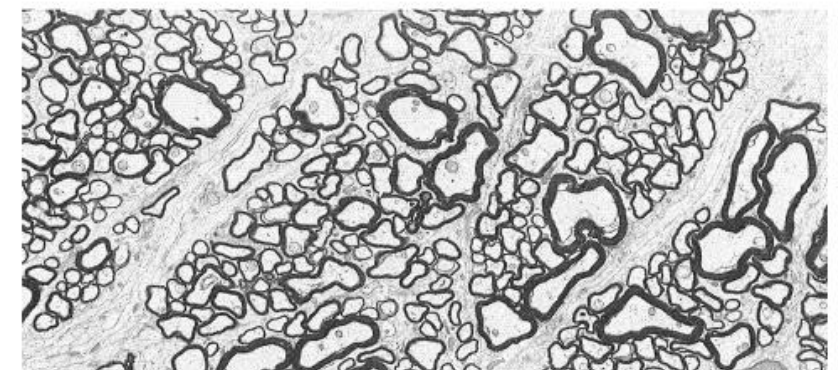

28.

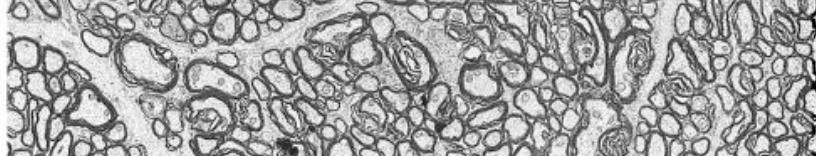

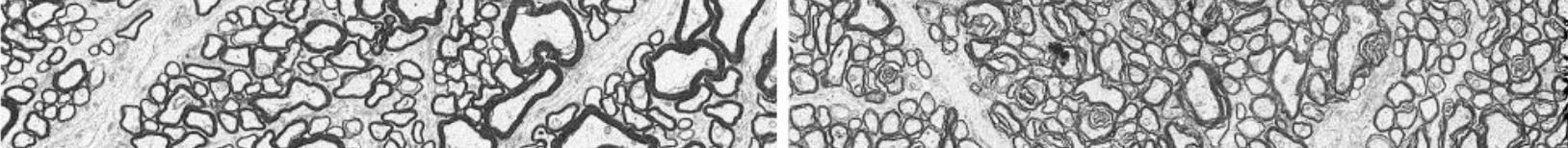
sig ती

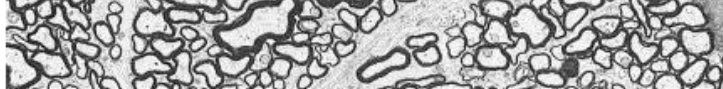

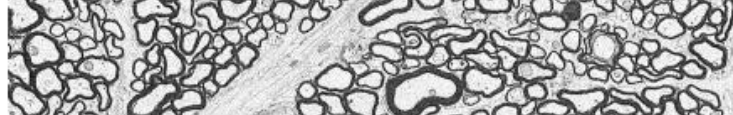

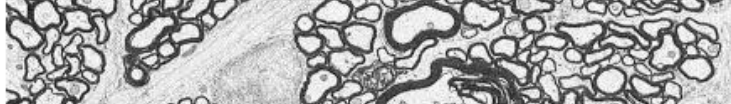

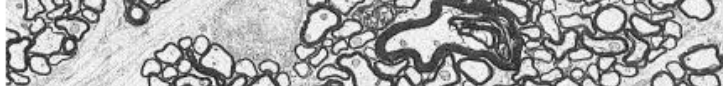

B

S.

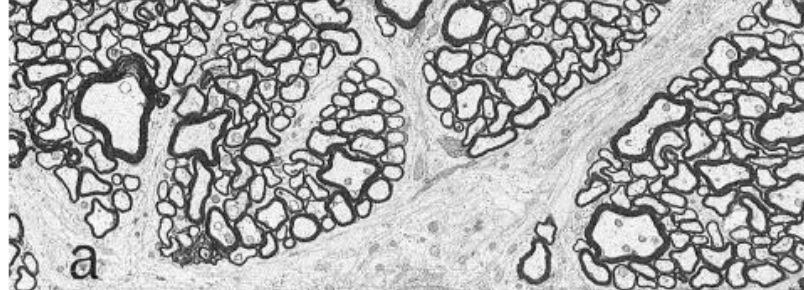

$\int_{3}$
070 som

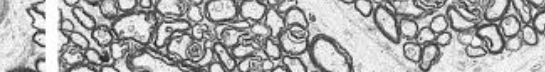

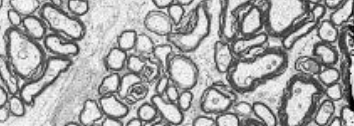

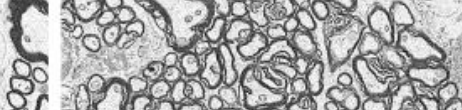

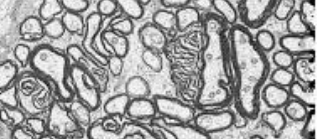

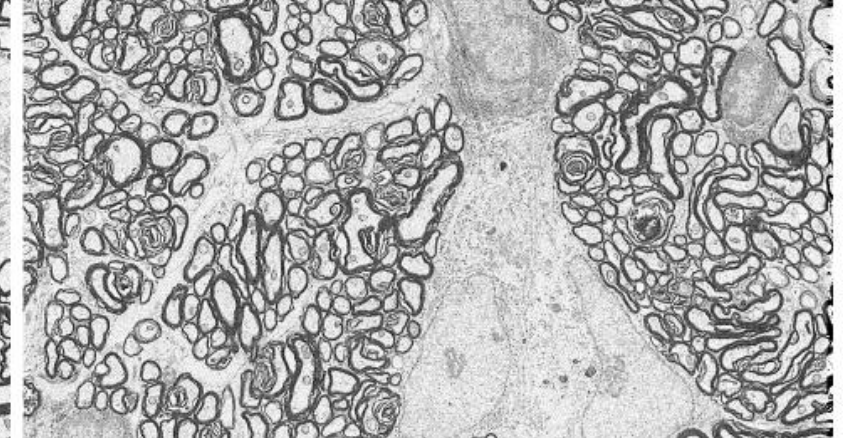

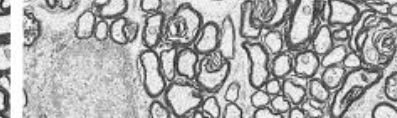
i.

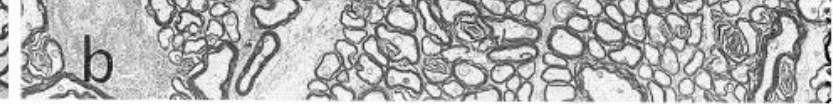

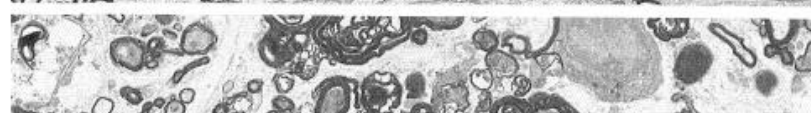

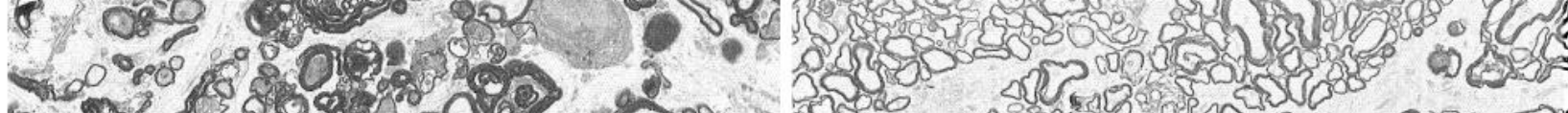

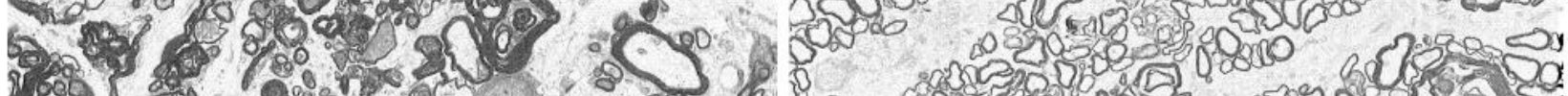

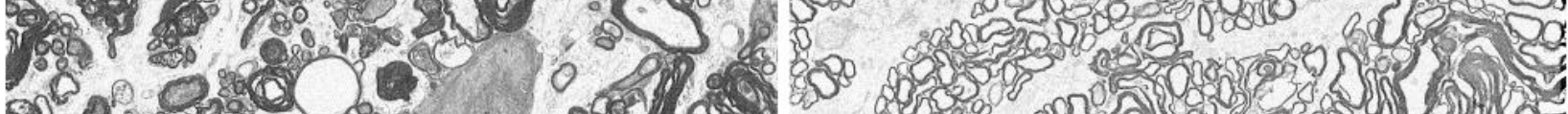

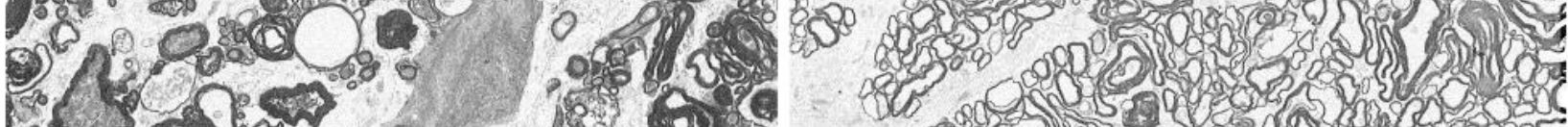
8 (2)

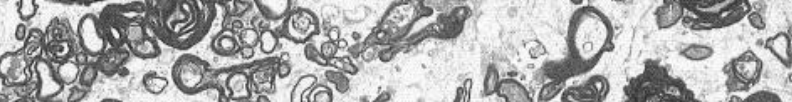

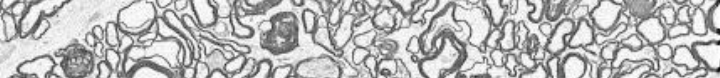

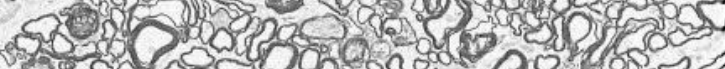

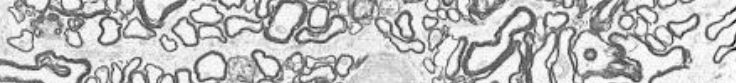
50. 8.

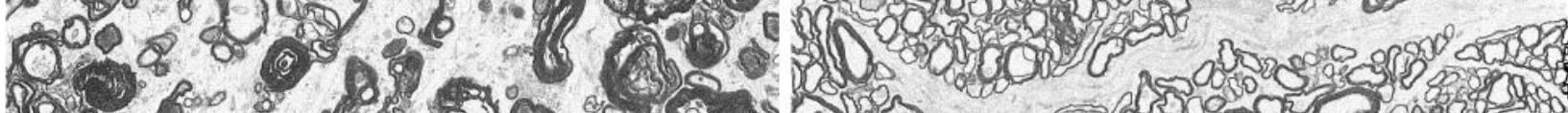

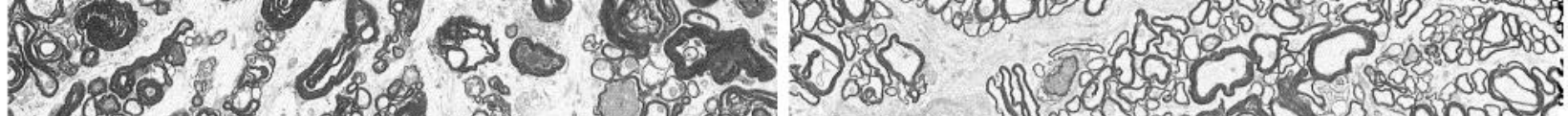

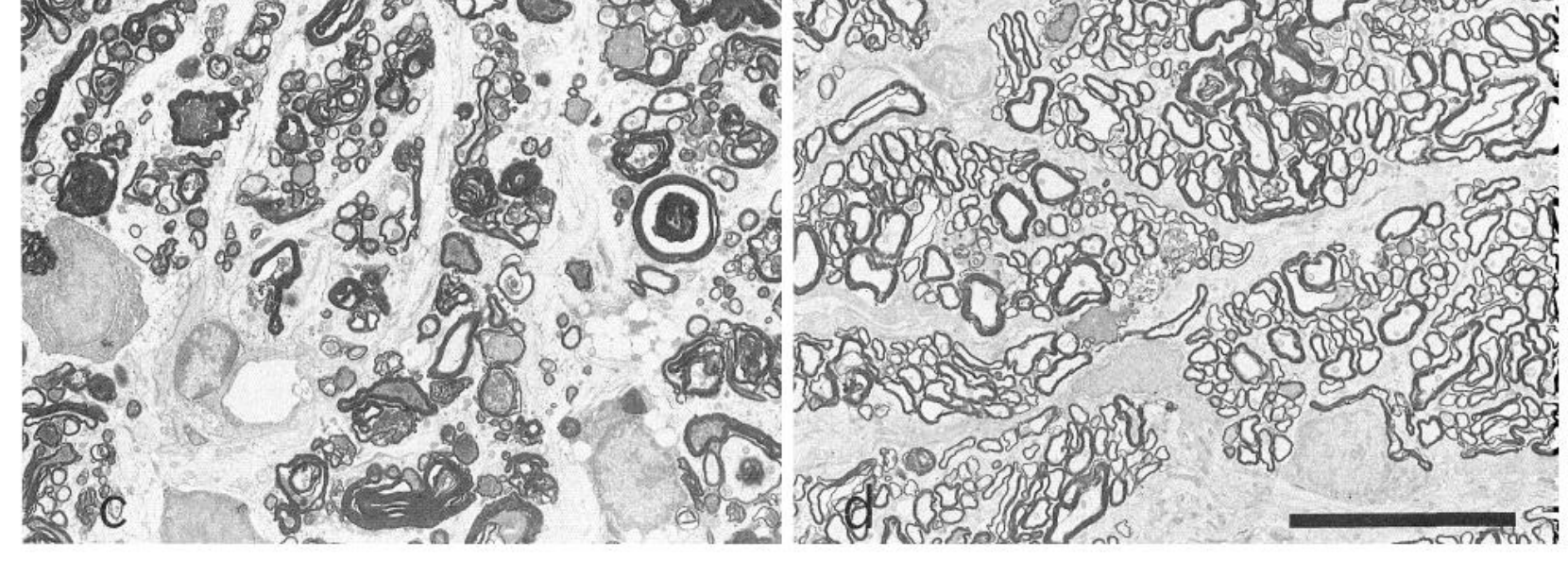


likely that the patterns of early cell death described here could be altered even more persistently by the timely and prolonged administration of specific molecules.

\section{References}

Allcutt D, Berry M, Sievers J (1984) A quantitative comparison of the reactions of retinal ganglion cells to optic nerve crush in neonatal and adult mice. Dev Brain Res 15:219-230.

Barron KD, Dentinger G, Krohel G, Easton SK, Mankes R (1986) Qualitative and quantitative ultrastructural observations on retinal ganglion cell layer of rat after intraorbital optic nerve crush. J Neurocytol 15:345-362.

Batistatou A, Greene LA (1991) Aurintricarboxylic acid rescues PC12 cells and sympathetic neurons from cell death caused by nerve growth factor deprivation: correlation with suppression of endonuclease activity. J Cell Biol 115:461-471.

Beer J, McKerracher L, Essagian C, Aguayo AJ (1993) Retrograde transport of neurotrophins in adult rat retinal ganglion cells. Mol Biol Cell, in press.

Berkelaar M (1992) Retinal ganglion cell loss after different types of axotomy in the optic nerve. Thesis, McGill University.

Bursch W, Kleine L, Tenniswood M (1990) The biochemistry of cell death by apoptosis. Biochem Cell Biol 68:1071-1074

Choi DW (1992) Excitotoxic cell death. J Neurobiol 23:1261-1276.

Clark G (1981) Staining procedures. Baltimore: Williams and Wilkins.

Clarke DB, Wang Y-C, Bray GM, Rasminsky M, Aguayo AJ (1993) Effect of neurotrophin-4 on the survival of axotomized retinal ganglion cells in adult rats. Soc Neurosci Abstr 19:1109.

Clatterbuck RE, Price DL, Koliatsos VE (1993) Ciliary neurotrophic factor prevents retrograde neuronal death in the adult central nervous system. Proc Natl Acad Sci USA 90:2222-2226.

Cohen $\Lambda$, Beer J, Bray GM, guayo $\Lambda \mathrm{J}$ (1993) Neurotrophin-4 (NT4) supports the survival of retinal ganglion cells and neurite outgrowth from adult rat retinal explants in vitro. Soc Neurosci Abstr 19:i 104.

Frisén J, Verge VMK, Fried K, Risling M, Persson H, Trotter J, Hokfelt T, Lindholm D (1993) Characterization of glial trkB receptors: differential response to injury in the central and peripheral nervous systems. Proc Natl Acad Sci USA 90:4971-4975.

Gavrieli Y, Sherman Y, Ben-Sasson SA (1992) Identification of programmed cell death in situ via specific labeling of nuclear DNA fragmentation. J Cell Biol 119:493-501.

Grafstein B, Ingoglia NA (1982) Intracranial transection of the optic nerve in adult mice: preliminary observations. Fxp Neurol 76:318330.

Hall S, Berry M (1989) Electron microscopic study of the interaction of axons and glia at the site of anastomosis between the optic nerve and cellular or acellular sciatic nerve grafts. J Neurocytol 18:171184.

Harvey AR, Robertson D, Cole KS (1990) Direcl visualization of death of neurones projecting to specific targets in the developing brain. Exp Brain Res 80:213-217.

Hefti F (1986) Nerve growth factor promotes survival of septal cholinergic neurons after fimbrial transections. J Neurosci 6:2155-2162.

Hendry IA, Campbell J (1976) Morphometric analysis of rat superior cervical ganglion after axotomy and nerve growth factor treatment. J Neurocytol 5:351-360.

Heumann R, Korsching S, Bandtlow C, Thoenen H (1987) Changes in nerve growth factor synthesis in non-neuronal cells in response to sciatic nerve transection. J Cell Biol 104:1623-1631.

Ilschner SU, Waring P (1992) Fragmentation of DNA in the retina of chicken embryos coincides with retinal ganglion cell death. Biochem Biophys Res Commun 183:1056-1061.

Jelsma TN, Friedman HH, Berkelaar M, Bray GM, Aguayo AJ (1993a) Different forms of the neurotrophin receptor trkB mRNA predominate in rat retina and optic nerve. J Neurobiol 24:1207-1214.

Jelsma IN, Friedman HH, Bray GM, Aguayo AJ (1993b) Expression of neurotrophins and neurotrophin receptors in adult rat retina and optic nerve. Soc Neurosci Abstr 19:254.

Johnson EM Jr, Deckwerth TL (1993) Molecular mechanisms of developmental neuronal death. Annu Rev Neurosci 16:31-46.

Johnson JE, Barde Y-A, Schwab M, Thoenen H (1986) Brain-derived neurotrophic factor supports the survival of cultured retinal ganglion cells. J Neurosci 6:3031-3038.
Korsching J (1993) The neurotrophic factor concept: a reexamination. J Neurosci 13:2739-2748.

LaVail MM, Unoki K, Yasumura D, Matthes MT, Yancopoulos GD, Steinberg RH (1992) Multiple growth factors, cytokines, and neurotrophins rescue photoreceptors from the damaging effects of con. stant light. Proc Natl Acad Sci USA 89:11249-11253.

Lu B, Yokoyama M, Dreyfus CF, Black IB (1991) NGF gene expression in actively growing brain glia. J Neurosci 1 1:318-326.

Mansour-Robaey S, Clarke DB, Wang Y-C, Bray GM, Aguayo AJ (1994) Effects of ocular injury and the administration of brain-derived neurotrophic factor (BDNF) on the survival and regrowth of axotomized retinal ganglion cells. Proc Natl Acad Sci USA 91:1632-1636.

Martin DP, Schmidt RE, DiStefano PS, Lowry OH, Carter JG, Johnson EM (1988) Inhibitors of protein synthesis prevent neuronal death caused by nerve growth factor deprivation. J Cell Biol 106:829-844.

McKerracher L, Vidal-Sanz M, Essagian C, Aguayo AJ (1990) Selective impairment of slow axonal transport after optic nerve injury in adult rats. J Neurosci 10:2834-2841.

McKerracher L, Essagian C, Aguayo AJ (1993) Marked increase in $\beta$-tubulin mRNA expression during regeneration of axotomized retinal ganglion cells in adult mammals. J Neurosci 13:5294-5300.

Meyer M, Matsuoka I, Wetmore C, Olson L, Thoenen H (1992) Enhanced synthesis of brain-derived neurotrophic factor in the lesioned peripheral nerve: different mechanisms are responsible for the regulation of BDNF and NGF mRNA. J Cell Biol 1 19:45-54.

Misantone LJ, Gershenbaum M, Murray M (1984) Viability of retinal ganglion cells after optic nerve crush in adult rats. J Neurocytol 13: $449-465$.

Oppenheim RW, Schwartz LM, Shatz CJ (1992) Neuronal death, a tradition of dying. I Neurobiol 23:1111-1115.

Richardson PM, Issa VKM, Shemie S (1982) Regeneration and retrograde degeneration of axons in the rat optic nerve. J Neurocytol 11:949-966.

Sendtner M, Kreutzberg GW, Thoenen H (1990) Ciliary neurotrophic factor prevents the degeneration of motor neurons after axotomy. Nature 345:440-441.

Singer PA, Mehler S, Fernandez HL (1982) Blockade of retrograde axonal transport delays the onset of metabolic and morphologic changes induced by axotomy. J Neurosci 2:1299-1306.

Snider WD, Elliott JL, Yan Q (1993) Axotomy-induced neuronal death during development. J Neurobiol 23:1232-1246.

Thanos S, Bahr M, Barde Y-A, Vanselow J (1989) Survival and axonal elongation of adult rat retinal ganglion cells. In vitro effects of lesioned sciatic nerve and brain derived neurotrophic factor. Eur J Neurosci 1:19-26.

Thanos S, Mey J, Wild M (1993) Treatment of the adult retina with microglia-suppressing factors retards axotomy-induced neuronal degradation and enhances axonal regeneration in vivo and in vitro. $\mathrm{J}$ Neurosci 13:455-466.

Valenzuela DM, Maisonpierre PC, Glass DJ, Rojas E, Nunez L, Kong Y, Gies DR, Stitt TN, Ip NY, Yancopoulos GD (1993) Alternative forms of rat trkC with different functional capabilities. Neuron 10: 963-974.

Vaux DL (1993) Toward an understanding of the molecular mechanisms of physiological cell death. Proc Natl Acad Sci USA 90:786789.

Vidal-Sanz M, Villegas-Perez MP, Bray GM, Aguayo AJ (1988) Persistent retrograde labelling of adult rat retinal ganglion cells with the carbocyanine dye diI. Exp Neurol 102:92-101.

Villegas-Pérez MP, Vidal-Sanz M, Bray GM, Aguayo AJ (1988) Influences of peripheral nerve grafts on the survival and regrowth of axotomized retinal ganglion cells in adult rats. J Neurosci 8:265-280.

Villegas-Pérez MP, Vidal-Sanz M, Rasminsky M, Bray GM, Aguayo AJ (1993) Rapid and protracted phases of retinal ganglion cell loss follow axotomy in the optic nerve of adult rats. J Neurobiol 24:2336.

Williams LR, Varon S, Peterson GM, Wictorin K, Fischer W, Björklund A, Gage F (1986) Continuous infusion of nerve growth factor prevents basal forebrain neuronal death after fimbria fornix transection. Proc Natl Acad Sci USA 83:9231-9235.

Yip HK, Rich KM, Lampe PA, Johnson EM (1984) The effects of nerve growth factor and its antiserum on the postnatal development and survival after injury of sensory neurons in rat dorsal root ganglia. J Neurosci 4:2986-2992. 